\author{
Шевченко Лілія Михайлівна, \\ кандидат педагогічних наук, доцент, \\ доцент Одеської національної музичної академії \\ ім.А.В.Нежданової \\ ORCID 0000-0001-8602-9573 \\ lilia.my.forte@gmail.com
}

\title{
АКТУАЛЬНИЙ СОЦІО-КУЛЬТУРНИЙ ЗРІЗ ВИРАЗНОСТІ ФАНТАЗЇ̈ НА ТЕМИ РЯБІНІНА А. АРЕНСЬКОГО
}

\begin{abstract}
Мета роботи - простеження симультанних стильових показників твору А. Аренського, що торкається сьогоденних пост-поставангардних стильових вимірів його значеннєвості. Методологічною основою $\epsilon$ інтонаційний підхід школи Б. Асафьєва в Україні, у тому числі в його виконавському переломленні, як це має місце в роботах Т. Вєркиної, О. Маркової, М. Давидова, Л. Шевченко, Л. Зими й інших. Основні методи дослідження - музично-історичний, порівняльний, стильовий, герменевтичний, музично-культурологічний аналіз, представлених в працях О. Рощенко, О. Муравської й ін. Наукова новизна. Фантазія для фортепіано i оркестру А.Аренського демонструє типологічні семантично-структурні перетини, які відображають моністично вирішений космізм національного характеру у маскулінному зрізі. Адраматична поемність цілого втілює необарочну облігатність, відтворюючи неосимволістські відтворення quasi-сонатних форм у трнадиціях К.Дебюссі. Висновки. Неантитетична концертність твору Аренського, що відроджує барочний облігатний тип, який відверто опирається на духовне джерело цього жанру, апробує духовно-гимнічні підстави комбінаторики сформованих форм, показових для жанру фантазіі. В поставангардному - пост-поставангардному середовищі сучасності, відміченому, за О.Марковою, неосимволістським стильовим показником, твір Аренського складає актуальну для сучасних слухачів апеляцію до зв'язку з духовними ранньоконцертними жанровими ознаками.
\end{abstract}

Ключові слова: актуальний соціокультурний зріз виразності, жанр фантазії, піанізм, сучасна культура.

Шевченко Лилия Михайловна, кандидат педагогических наук, доцент Одесской наџиональной музыкальной академии имени А.В.Неждановой

Актуальный социо-культурный срез выразительности фантазии на темы Рябинина А. Аренского

Целью работы выступает прослеживание симультанных стилевых показателей в произведении А.Аренского, что дает касание современных пост-поставангардных стилевых измерений его смыслов. Методологической основой является интонационный подход школы Б.Асафьева в Украине, в том числе в его исполнительском преломлении, как это имеет место в работах Т. Веркиной, Е. Марковой, Н. Давыдова, Л.Шевченко, Л. Зимы и других. Ведущие методы исследования - музыкально-исторический сравнительный стилевой, герменевтический, музыкально-культурологический, представленых в трудах, кроме вышеназванных, у Е. Рощенко, О. Муравской и др. Научная новизна. Фантазия для фортепиано и оркестра А. Аренского демонстрирует типологические семантически-структурные пересечения, которые отображают монистически решенный космизм национального характера в маскулинному срезе. Адраматическая поэмность целого воплощает необарочную облигатность, воссоздавая неосимволистское воспроизведение quasi-coнатных форм в традициях К.Дебюсси. Выводы. Неантитетическая концертность произведения Аренского, возрождающего барочный облигатный тип, который откровенно опирается на духовный источник этого жанра, апробирует духовно-гимнические основания комбинаторики сформированных форм, показательных для жанра фантазии. В поставангардной - пост-поставангардной среде современности, отмеченной, по Е.Марковой, неосимволистским стилевым показателем, произведение Аренского составляет актуальную для современных слушателей апелляцию к связи с духовными раннеконцертными жанровыми признаками.

Ключевые слова: актуальный социокультурный срез выразительности, жанр фантазии, пианизм, современная культура.

Shevchenko Lilia, candidate of the pedagogical sciences, assistant professor, Odessa national music academy of the name A.V.Nezhdanova

Actual socio-cultural cut of expressiveness in fantasies on themes of Ryabinin to A. Arenskiy

The purpose given work emerges the trailing of the simultation style factors in works of A. Arenskiy that gives the osculation modern post-postavanguard style measurements his sense. The methodology is intonation approach of the school B.Asafiev in Ukraine, including in his performance refraction as in the case in work T.Verkina, E.Markova, N.Davydov, L.Shevchenko, L.Zima and others. The leading methods of the study - music-history comparative style, hermeneutic, music-cultulorogy, which are presented in works, except above named, besides A. Roschenko, O.Muravskaja and others. Scientific novelty. The Fantasy for piano and orchestra of A. Arenskiy demonstrates the typology semantic-structured intersection, which display the monistic solved cosmism of national nature in maskuline cut. A dramatic poeming of whole incarnate neobaroque obligato, reconstructing neosymbolism

(C) Шевченко Л. М., 2019 
reproduction of quasi-sonata forms in the tradition of C.Debussi. Conclusions. Non-antithetic concert type of Arenskiy work, reviving baroque obligato type, which frankly rests in the spiritual source of this genre, a approve spiritual-hymn basis of combination to formed forms, significant for the genre of fantasies. In postavanguard - post-postavanguard ambiance to contemporaneity, noted, on E.Markova, by neosymbolism style factor, Arenskiy word forms actual for modern listeners appeal to a relationship with the spiritual early concert-genre sign.

Key words: actual socio-cultural cut of expressiveness, genre to fantasies, pianism, modern culture.

Актуальність теми дослідження визначена виключною затребуваністю у концертному i учбовому репертуарі Фантазії на теми Рябініна А. Аренського, популярність якої перевищує явно інше написане цим композитором. При цьому посилання на билинний епічний пласт, показовий для російської культури, викликає ентузіазм і в аудиторіях України, оскільки билинний сегмент зобов’язаний своєю генезою богатирству Київської Русі, яка $є$ географічно і фактично витоком українського культурного феномену. Численні виконання цього твору свідчать про затребуваність, у тому числі сучасною аудиторією, у якій перетинання академічних і популярних стильових шарів («кітч-ефект» поставангардного й пост-поставангардного артистичного сьогодення) провокують особливого роду адраматичні структури вираження, закладені в епічні складові твору А. Аренського. Відповідно, зазначений твір композитора неодноразово ставав предметом дослідження, однак актуальний стильовий показник причетності до сучасного кітч-принципу не висувався.

Метою роботи $є$ простеження симультанних стильових показників, закладених у твір А.Аренского, що торкається сьогоденних пост-поставангардних стильових вимірів його значеннєвості.

Виклад основного матеріалу. Фантазія А.Аренського на теми Рябініна становить ніби безпосередню проекцію музичного досвіду російської Півночі, що $є$ органічною для народженого в Новгородській губернії Антонія Аренського. Однак історичний зв'язок Новгорода й Києва відомий, а тип мовного спілкування цієї ділянки північноросійського ареалу зберігає контакт із фонетикою України: у новгородців вимова надзвичайно м'яка, як у киян, що різко відрізняє їх мовлення від петербурзького говору, хоча це надзвичайно географічно близькі міста. Але, властиво, саме тут, на Півночі Русі, збереглися билинні записи Київського циклу, які й стали предметом творчої подачі Аренського в його фортепіанно-оркестровій Фантазії.

Фантазія написана в тональності $e$, що чітко ввійшла в естетику XIX століття як тональність ідеального стану романтиків. Такий тональний рівень має особливу вагу в історії музики, про що спеціально говориться в дослідженні Лін Цюньда у зв'язку з тональністю Дев'ятої сонати Л.Бетховена:

«Тональність Е-dur Дев'ятої сонати займає спеціальне місце в спадщині композитора, будучи тональністю Увертюри 'Леонора № 3', також однойменної до устою Другого з Російських квартетів (№ 8 у нумерації Квартетів), це також тональність (однойменна) Двадцять сьомої й Тридцятої сонати, тобто однісї з п'яти останніх Сонат Бетховена, що становлять великий завіт наступним поколінням у типології цього жанру. При цьому Дев'ята соната за суттю ладового орієнтування - Е-dur співвідносна саме із Тридцятою, однією із самих 'романтичних' - в 'проторомантичній' п'ятірці останніх творів композитора... До речі, саме Восьмий квартет, як той що займає серединне положення в Російських квартетах (№№ $7,8,9$ ), також відзначаємо у зв'язку з 'проторомантичними' елементами вираження» [5, с. 32-33].

Далі цитований автор указує, що для романтиків E-dur/e-moll склали «тональність ідеального стану», тоді як для Й.С.Баха така тональна підвалина утворювала різновид «пасторальної» тональності - під пасторальністю малася на увазі «Гармонія природи» як втілення ідеального порядку в матеріальних проявах. Вказується, що для всіх названих авторів базисною була система Піфагора в трактуванні виразних можливостей висотно-тональних принципів: якщо висотності А/a, $\mathrm{B} / \mathrm{b}, \mathrm{C} / \mathrm{c}$ указували на небесні ідеальні сутності, $D / d$ - «серединне», те $E / e, F / f$ представляли «матеріальний» світ [3, 239] (звідси в Середньовіччі виділялося сумне «коло» miseria-fames-miseria, еf-e - « убогість-голод-убогість» душі [4, 198-199]).

Правда, істотною $є$ піфагорейська ж корекція: «груба матерія не предмет музики» [3, 27]. Від чого «матеріальне» у визначенні семантики тональностей $E / e, F / f$ передбачалося як втілення «стихій», «розрідженої» матерії води-вогню-повітря. У всякому разі від індійських Вед і аж до Древньої Палестини й класичної Грецької Античності йде традиція виділення ладів $e$ як призначених втілювати земну-людську ідеальність (лад «крові й життя» у веддичній Індії $[8,17]$, тон псалмів у Палестині, основний тон Дельфійського гімну на честь Аполлона в Древній Греції) [6, 33].

У зв'язку із творчістю Бетховена показово те, що всі названі твори композитора в E/e відзначені «співучістю» своїх тим, і в цьому багато в чому вбачався «проторомантизм» Восьмого 
квартету й Тридцятої сонати. Дев'ята соната також кантово-«співуча», але в межах классицистской кантиленности (як і «Леонора» № 3). Очевидно те, що Бетховен «розсував» значимості E/e і $F / f$, підкреслюючи «пасторальність» другої і представивши в цих однойменних тональностях такі знакові для нього твори як «Пасторальна» симфонію, «Аppassionata», Перший, Сьомий, Десятий i Шістнадцятий квартети, ін., у яких природне й людське єства зближені полюсами прояву грози-гніву й замилуванего спокою.

I далі в дослідженні Лінь Цюньда висувається гіпотеза - про значеннєву спорідненість для Бетховена сфер $e$ i $f$, що визначає деяку авторську спеціальну позицію:

«I все-таки, генетична зближеність виразності тональних рівнів $E / e$ й $F / f$ як тих, що за Піфагором втілювали виразність 'матеріальних стихій' ..., а в техніці звуковираження людини відзначали грань природного й фальш-регістрів, подвигла, по всій імовірності й Бетховена, коли він в 1801 р. зробив транскрипцію Дев'ятої сонати для струнного Квартету (реалізувався кантовий потенціал тематизму!), перевівши, як в 'більше зручну', на думку коментаторів [39], для струнников тональність F/f.» [5,34].

У романтиків зазначені тональні сфери диференціюються, що визначає самозначимість сфери E/e у творчості Ф.Шопена (див.тональність Етюду № 3 ор.10, образ якого композитор зв'язував 3 образом Батьківщини), Дж.Верді (див. партію Джільди в «Ріголетто», Азучени в «Трубадурі», Дездемони в «Отелло»). В останньому випадку, в «Отелло», є «перетікаємість» значимостей $E / e$ й $F / f$, оскільки тема кохання у фіналі I дії проходить і в $E$, і в $F$, на тій же темі в $F$ вибудуваний фінал III дії (Плач Дездемони за контуром теми кохання в $F$ ), закінчується опера звучанням теми кохання в $E$.

3 тональністю $e$ пов'язана характеристика Лакме в однойменній опері Л.Деліба (1876), що була надзвичайно популярною в публіці й професійних колах. Стихія травневої ночі в I акті «Брингільди» і Лісу в II дії «Зігфріда» Р.Вагнера втілені в Е-dur. Єдність Е-dur - cis-moll визначає сферу Лізи в «Піковій Дамі» П.Чайковського й Мелізанди в «Пеллеасі» К.Дебюссі. І якщо остання 3 названих опер стала найближчою перспективою реалізації «лейттональності століття» у передачі романтичного Ідеального стану, то всі попередні утворили актив пам'яті А.Аренского до часу творення у 1899 р. аналізованої Фантазії.

До пори написання зазначеної композиції цілком сформувався метод купкістського фольклоризму, для якого показовою $є$ ретельність внесення архаїчних елементів фольклорної традиції в прийоми фактури професійного мистецтва. Аренський новаційно вирішує переломлення «варіацій на народні теми» у вигляді концертної поеми для фортепіано-соло й оркестру, що утворюєь вільне переломлення концертно-симфонічних творів франко-бельгійської школи: «Джини» (1884) i «Симфонічні варіації» (1885) С.Франка й ін.

В основу твору покладені два билинних наспіви - про Іллю Муромця й про Вольгу Святославовича. Ілля Муромець втілює лицарське Служіння рідній землі по благословенню святих Мандрівників. А билина про Вольгу містить надзвичайно показове змішання християнської цілеспрямованості дій княжича в єдності 3 характерними для кельтського «давньозахідного православ'я» [10] достоїнствами чаклунства заради блага єдинокровних. Мелодійно обидва наспіви підлягають епічному строю викладу за хвилею арсис - тезис, що показує рух ходи вниз від високого до низького акценту. Однак, як відзначено вище, персонажі билин представляють принципово різні фігури, у тому числі в релігійно-міфологічному вимірі: очевидні слов'янстко-християнські підстави першого й кельтско-волховськї показники другого.

Судячи з того, як фактурно розпорядився А.Аренський, представляючи теми цих двох билин, він чітко усвідомлював розходження етнічно-світосприйнятних аспектів билинних героїв: перша тема дана в повноті кантиленного представництва мелодії на тлі гіпертрофовано «гуслевидних» пасажних «пробігів», тоді як друга (від т. 56) явно відзначена скерцозною подачею (Allegretto), компактним акордовим викладом.

Перша тема явно представляє нормативно-епічний тип викладу, героя могутнього й стабільного у своїй багатирській іпостасі, а також в аналогії з тематичною експозицією поліфонічної форми типу фуги. На користь зазначеної аналогії свідчить як унісонне звучання теми, в основу якої покладений вихідний мотив билинної мелодії, але до якої приєднаний патетичний зворот з ходом на широкий інтервал ( $\mathrm{h}-\mathrm{a}-e^{I}-d i s^{l}-g^{I}-f i s^{l}$, тт. 1-2). На користь аналогії з поліфонічною формою працює наступне проведення цього роду теми на кварту вище, тобто за типом тональної відповіді в експозиції фуги від $e$ (тт. 2-4). Наступні проведення теми, у якій билинний зворот сполучений 3 патетичним ходом пробахівського мелодизму, знову демонструють співвідношення поліфонічної експозиції тема - відповідь, тільки в розвиваючому вільному інтервальному співвіднесенні на збільшену кварту - від $c$ i fis (див. тт. 4-8 і 8-11), із включенням пасажно представленого патетичного 
вигуку (тт. 7-8), і ускладненого дублями розбіжних контурів catabasis (ліва рука) i anabasis (права рука) у тт. 9-11.

Так фактурними засобами задається контактність билинної мелодії з темою церковно-ученої музики, що успадковує досвід бетховенських творів типу початкової теми П'ятої симфонії або I частини Тридцять другої сонати ор.111 Л.Бетховена. Щось близьке до сказаного представлене в експозиції першої теми увертюри до «Майстерзінгерів», що проголошує музичну емблематику Майстерзанга в зазначеній опері Р.Вагнера. Ладова неоднозначність цієї першої й основної теми твору підкреслена ефектом гармонійної вертикалі «тоніки із секстою» (від т. 11), а далі й «домінанти із секстою» (у тт. 13-16), - до речі, що займає велике місце в джазовій гармонії, народжуваної хронологічно одночасно із твором Аренського (чуйність композитора до «духу часу»...[2]).

Слід зазначити, виділеність «тоніки із секстою» як квінтесенції гармонійного світовідчуття музики напочатку XX століття відбито у вихідній темі «Пісні про землю» Г.Малера, у якій I частина «Застільна пісня про нещастя землі» вибудувана на педалі вищезгаданої тоніки із секстою від $a$, 3 підкресленням мелодійної опорности співвіднесень е- $f$ як лейтобразу музики $X X$ століття, щзо втілює Драму Духа, минаючи драму пристрастей і характерів попередніх епох.

Друга тема (від т. 56) вказує на заповзятливість і ненормативну активність героя билини про Вольгу, на його «перетворюваність», можливо, тому ладовий тонус теми «ковзає», формально це $a$ фригійський, але $з$ такими ж підставами можна висувати концепцію домінантового ладу від $d$. Фактура подачі теми - акордово-партесна, але нон-легатне представлення надає звучанню «дивність», «невпізнаність». Наступний розвиток теми використовує щось типу варіацій-остінато, у дусі так званих глінкинських варіацій, оскільки контрапунктуючі «прямі» лінії утворюють яскраву контурну протилежність основному quasi-партесному вигляду самої теми.

Передрепризне відхилення в $F / b$ (т.103, Più mosso) створює нагромадження енергії, що захоплює початок репризи (порівн.з ефектом бетховенських реприз), оскільки перше речення першої - по-богатирськи-«нормативаної» - теми й показувана в основній тональності $е$ друга тема йдуть на домінантовому органному пункті. Однак, у контексті плагальних ладових установок звучання тем, дана формально домінантова педаль включена в тонікальний комплекс домінантових ладів від $e$, що визначає, не як у Бетховена, нагромадження напруги устремління до розрядження, але до нагромадження тонікальної маси.

У репризному проведенні (Теmpo I, т. 114) відновлення експозиційного вигляду першої теми здійснюється в контрапункті з темою другою, підкреслюючи рівновеликість традиції богатирства і іiі вченого перетворення. Так позначається досвід внесення в трактування сонатної репризи принципу поліфонічної форми подвійної фуги, як це здійснено в репризі увертюри до «Майстерзінгерів» Р.Вагнера й інше. Наступний етап репризи - знову роздільне звучання тем (від т.125, друга тема від т. 141).

У коді (Andante sostenuto, т.148) знову затверджується перша тема - але в гармонійному й фактурному відновленні, оскільки «вбирає» партесний склад експозиції другої теми, але в позбавленні нон-легатних «перетворень», а також у багатстві ладових сполучень домінантового аmoll, d-moll у єдності з тонікальною зазначеністю e-moll, в останніх тактах позначених ще й гармонічно «ортодоксальним» ходом мелодійного мінору.

Проведений аналіз свідчить про високу позарядовість твору А.Аренського, зовні ніби успадковуючого численні зразки подвійних варіацій, які мали місце у західноєвропейських авторів, у Бетховена, зокрема (Третя симфонія й ін.), в російських композиторів (класика - «Камаринська» Глінки). Однак Аренський зовсім оригінально склав концепцію билинності, визначивши гідну хронологічну паралель творам Р.Штрауса цих же років («Тіль Уленшпігель», «Дон Кіхот»), у яких також запропоноване аж ніяк не бетховенське трактування зазначеної архітектонічної типології подвійних варіацій.

I знову мова йде не про запозичення - у Росії не могли бути виконані твори німецького майстра, що тільки створював їх. Це - уловлювання «духу часу» [2], це торкання геніальності дара російського композитора, називаного не в періоме ряді геніїв слов'янської музики кінця XIX початку XX століття, однак у даному творі гідно визначившого вихід на світовий рівень професіоналізму у надзвичайно своєрідному об'єднанні ознак мислення Петербурзької й Московської шкіл.

I знову - чуйність до «духу часу»: одночасно з Аренським працював М.Регер, що ввійшов в історію музики тим, що сполучив показники мислення вагнерівського й брамсіанського блоків виразних засобів. Ще аналогія відкриттям геніїв кінця XIX - початку XX століття в Аренського, це співвіднесеність із Г.Малером, якого цінували в Росії як диригента, а Малер пієтично звертався до 
П.Чайковського й у його особі до Московської школи, хоча творів цього зростаючого композитора щиро не чули.

Але Малер за принципами мислення вважав себе вагнеріанцем, хоча свідомо орієнтувався на спадщину І.Брамса: характерна для зазначеного часового періоду тяга до «стирання антитез», що охоплювала не тільки стилістичні розмежування в мистецтві, але була й фактом політичного життя.

Початок зазначеному «зближенню протилежностей» покладено було Декларацією символістів 1886 року, що мала знаменну присвяту: пам'яті Г.Кюрбе. Загиблий у розгромі Паризької Комуни 1872 p., Г.Кюрбе символізував політичний радикалізм великих представників французького мистецтва, належного бути перебореним заради національної єдності країни. Пошуки примирення протиріч соціально-політичного, державно-національного порядку займали уяву багатьох видатних розумів зазначеної доби, у тому числі це й висування ідеї «Сполучених Штатів Свропи» Миколою II. Це й пропозиції «заміни» соціальних революцій - культурним «переозброєнням» націй через...нове містобудування. Таким є німецький "Werkbund", у якому виоробничо-аскетична архітектура покликана була уніфікувати житло всіх прошарків і класів населення, виключаючи протистояння i соціальні конфлікти.

На порядку денному мистецтва стають містеріальні концепції, у ряді яких самостійне місце одержують «психодрами» В.Ребікова («Драма Духа»), символістська драма й містерія К.Дебюссі, проект Містерії О.Скрябіна й ін., покликані планетарно охопити уяву людей у спрямованості на гармонізацію соціуму й мистецтва. Класика музичного мистецтва Нового часу - мистецтво опери як музичної драми, тоді як для О.Скрябіна спливла концепція втілення в музиці «нетрагізму буття» [9, 35]. У контексті сказаного твір А. Аренського виступає в повноті втіленняя в ньому «імпульсів часу», найважливіших парадигматичних показників планетарного художнього тонусу, завдяки наявності якого освоєний Новою російською школою билинний фольклоризм у професійній творчості знаходить принципово нове ємне стильово-жанрове наповнення. Ця новизна - від усвідомлення билинного мотиву не як «переказ старовин глибоких», але як актуалізований в пасажності-етюдності академічного піанізму зв'язок з первинно-значущими символами, чи то збереженими колективною свідомістю народу, чи то виплеканими церковною ритуаликою із глибин релігійного інстинкту.

У концепції форми Фантазії Аренського наявною є ідея про «поглинання діалогічності монологом», засвідчуючи багатоликість колективного суб'єкту билинних подій. Надособистісна лірика в епічно-оповідальному викладі утворює завоювання нового етапу трактування жанру фантазії, у якому передвіщений Глінкою в «Камаринській» космізм трактування компенсативності чоловічого - жіночого в національному баченні перетворюється в маскулінізоване богатирство в поданні національного образу слов'янської традиції.

Історично-часово такий ракурс російського національного характеру співвідносимо 3 маскулінно ж орієнтованим надгероєм Ф.Ніцще, що також абстрагувався від жіночої участі в героїчному дійстві життя. I одночасно це утворює реакцію на сюжети А.Стрінберга, що опонував Г.Ібсену, представляючи чоловічий стоїцизм як стрижень національного самоствердження, демонструючи порочність і слабкість жіночої складової людського співтовариства.

У виконавській діяльності одеських піаністів Фантазія на теми Рябініна А.Аренського від початку визначилася як один 3 найбільш репертуарних творів, у тому числі в навчальних виступах студентів консерваторії.

Проаналізований твір А.Аренського явно передує монологічному вирішенню обох Концертів для фортепіано з оркестром О.Глазунова, діяльність якого пов'язана з Одесою (ще в 1920-ті Друга музична школа одержала почесне звання імені Глазунова). Монологізований - не по-лістівськи антитетично, але лірично цілісно - варіант представлений у фортепіанному Концерті В.Косенко. I ця ж ідея сукупно-ліричного впливу колективного суб'єкта слов'янських націй має місце в Слов'янському кониерті Б.Лятошинського.

Наукова новизна. Фантазія для фортепіано і оркестру А.Аренського демонструє типологічні семантично-структурні перетини, які відображають моністично вирішений космізм національного характеру у маскулінному зрізі. Адраматична поемність цілого втілює необарочну облігатність, відтворюючи неосимволістські відтворення quasi-сонатних форм у традиціях К.Дебюссі.

Висновки. Неантитетична концертність твору Аренського, що відроджує барочний облігатний тип, який відверто опирається на духовне джерело цього жанру, апробує духовно-гимнічні підстави комбінаторики сформованих форм, показових для жанру фантазії. В поставангардному - постпоставангардному середовищі сучасності, відміченому, за О.Марковою [7, 99-133], неосимволістським стильовим показником, твір Аренського складає актуальну для сучасних слухачів апеляцію до зв'язку з духовними ранньоконцертними жанровими ознаками. 


\section{Jimepamypa}

1. Асафьев Б. Музыкальная форма как процесс. Москва-Ленинград: Музыка, 1971. 379 с.

2. Гегель Г. Лекции по истории философии... см. «Дух своего времени» Der Geist seines Zeit. URL: https: // ru.wikipedia.org / wiki / Дух_времени (дата зверення: травень 2018). 1995. $289 \mathrm{c}$.

3. Гудман Ф. Магические символы. Москва: Издат. Ассоц. Духовного объединения «Золотой век»,

4. Левая Т., Леонтьева О. Пауль Хиндемит. Москва: Музыка, 1974. 448 с.

5. Линь Цюньда. Соната Л. Бетховена № 9 ор.14 в ряду ранних сочинений композитора. Магистерская работа. ОНМА имени А.В.Неждановой. Одесса, 2017. 57 с.

6. Лосев А. Античная музыкальная эстетика. Москва: Музыка, 1960. 194 с.

7. Маркова Е. Проблемы музыкальной культурологии. Одесса, Астропринт, 2012. 164 с.

8. Музыкальная эстетика стран Востока. Ред. В.Шестаков. Москва: Музыка, 1967. 414 с.

9. Южный музыкальный вестник. 1915. №№ 8-9. С.3-5.

10. Vita patrum. Житие Отцов, составленное святителем Григорием Турским. Предисловие отца Серафима (Роуза). Москва: Издат. дом Русский Паломник, 2005.370 с.

\section{References}

1. Asafiev, B. (1971). Music form as process. Moscow-Leningrad, Muzyka. [in Russian].

2. Hegel, G. Лекции по истории философии... см. «Дух своего времени» Der Geist seines Zeit. URL: https: // ru.wikipedia.org / wiki / Дух_времени [in Russian]. Russian].

3. Goudman, F. (1995). Magic symbols. Moscow, Izdat.Assoc.Duhovnogo objedinenija «Zolotoj vek». [in

4. Levaja, T., Leontjeva O. (1974). Paul Hindemith. Moscow, Muzyka [in Russian].

5. Lin Jun, Da Sonata of 1. Beethoven № 9 op.14 in early works of the composer

6. Losjev, A. (1960). Antique music esthetics. Moscow, Muzyka [in Russian].

7. Markova, E. (2012). The problem of music culturology. Odessa, Astroprint [in Ukrainian].

8. The music aesthetics of the countries of the Orient. (1967). The edit. V.Shestakov. Moscow-Leningrad, Muzyka [in Russian].

9. South music herald (1915). №№ 8-9. P.3-5 [in Ukrainian].

10. Vita patrum. The life of Fathers, formed prelate Grigory Tursky (2005) . The foreword of father Seraphim (Raus). Moscow, Izdat.dom Russkij Palomnik. 370 p. [in Russian].

Стаття надійшла до редакції 10.02.2019 p. 